\title{
Research Progress of Border for Solar Photovoltaic Modules
}

\author{
Wang Xingxing \\ School of Mechanical Engineering \\ Nantong University \\ Nantong, China \\ E-mail: wangxx@ntu.edu.cn
}

\author{
Lu Haoyang \\ School of Mechanical Engineering \\ Nantong University \\ Nantong, China \\ E-mail: familyylxq@163.com
}

\author{
Ni Hongjun* \\ School of Mechanical Engineering \\ Nantong University \\ Nantong, China
}

\author{
Lu Wenfan \\ School of Mechanical Engineering \\ Nantong University \\ Nantong, China \\ E-mail: 1508699921@qq.com \\ Zhang Minqi \\ Engineering R\&D center \\ Jiangsu Lead Aluminum Co., Ltd \\ Nantong, China \\ Zhang Yongpei \\ Engineering R\&D center \\ Jiangsu Lead Aluminum Co., Ltd \\ Nantong, China
}

\begin{abstract}
With the sustainable development of economy, sol ar energy has been widely used as a clean energy, photovolta ic industry has been rapid development. This article summar izes the summary and classification of solar photovoltaic mo dules frame; Comparative analysis is mainly focused on the aluminum frame, stainless steel frame and composite frame etc. The advantages and disadvantages of solar energy photo voltaic component frame; Aluminum frame, with its good pe rformance, the advantage, low cost and large-scale applicatio n. Also expounds on the role and structure and fixed way an d way of surface treatment of aluminum frame, and the stru cture of different, contrasted the fixed way and surface treat ment method, analyzes its advantages and disadvantages. Fi nally this paper summarizes the present status of solar photo voltaic modules border, summarizes the problems that exist $i$ $n$ the solar photovoltaic modules border, and explains the ca uses of the problem; Put forward the photovoltaic componen $t$ frame will towards lightweight, refinement, high strength, $t$ he direction of integration.
\end{abstract}

Keywords-Solar;PV modules;Border;Encapsulation; alumi num;

\section{INTRODUCTION}

The growing economy, energy supply will receive a lar ger, more severe test, to save on energy, environmental pro tection, known for solar will be widely welcomed. Solar ha $\mathrm{s}$ the characteristics of renewable and environmental protec tion, so many countries, including China, the solar energy $i$ ndustry as a new focus on the development. With the wide spread use of solar energy, photovoltaic industry rapid dev elopment, as of the end of 2014, China's total installed cap acity reached 30GW, second only to Germany, in 2030 this figure is expected to reach $270 \mathrm{GW}$,described prospects. A lthough in the solar photovoltaic system, the cost and techn ical difficulty of the components of the border are not large, but the role of the border is very important ${ }^{[1]}$. Border can $n$ ot only protect the glass on the solar panel, and also to facil itate the connection between the fixed components, while $t$ he Border and seal assembly binder constitute, as an assem bly the connection carrier building or stent, and its perform ance will affect the solar energy life of components. Curre ntly, the vast majority of domestic production of the alumi num alloy frame, the technology is relatively mature. Now is to study some of the composite materials Border, and the Border structure is optimized to improve its sealability, re duce the weight of the border, and cost savings. China as a major producer and supplier of Border, the border continuo us development of industry, this article on the current statu $\mathrm{s}$ of research made a presentation, and the prospect of futur e trends.

\section{SOLAR PHOTOVOLTAIC MODULES FRAME}

CLASSIFICATION AND ANALYSIS OF THE CHARACTERISTICS.

In accordance with the use of raw materials can be div ided into three categories of solar frame: Aluminum frame, Stainless steel frame, Composite material frame.

\section{A. Aluminum frame}

Aluminum profiles existing solar PV modules used primarily for the Model 6000 series Al-Mg-Si alloys, primarily for use in general is 6061 and $6063^{[2]}$.Its surface is silver-white thin film, the main ingredient is aluminum, mixed with a small amount of magnesium, copper, iron, silicon, zinc and other metals. At present, the solar industry as a producer of solar modules aluminum frame of the main material.

Aluminum with light weight, strong corrosion resistan ce easy forming, high strength, easy cutting and processin $\mathrm{g}$, recyclable and other characteristics of the current frame in the application of solar energy is most common, accou nting for more than $95 \%{ }^{[3]}$. 


\section{B. Stainless steel frame}

Limited alternatives as stainless steel frame aluminum frame structure similar to aluminum alloy fram ${ }^{[4]}$. Genera lly use 304 stainless steel plate through a special process t hat can adapt to different environments, and relatively hig $\mathrm{h}$ intensity. Due to high prices, the production process is more complicated, so relatively low utilization.

\section{Composite material frame}

Composite material frame mainly refers to glass, steel, namely glass fiber reinforced polymer composites. It is a glass fiber and its products (glass cloth, ribbon, felt, sand, etc.) as a reinforcing material, synthetic resin as Composite material matrix. FRP profiles currently being used in a small number of British rooftop solar cell module, but because of its plasticity is not strong and not recyclable, does not have an advantage in terms of cost, it is not widely used ${ }^{[5]}$.

In addition to the three borders, industrial plastic frame is a new product in recent years, the industry concerned. However, due to the terms of industrial plastic production time temperature, production speed, mold equipment, high demand, and environmentally sensitive polymer materials, once the temperature exceeds the critical value, the overall mechanical properties will be greatly reduced, the actual promotion of industrial plastic frame in phase there is a big uncertainty.

\begin{tabular}{|c|c|c|c|}
\hline & FRP & Stainless steel & $\begin{array}{c}\text { Aluminum } \\
\text { alloy }\end{array}$ \\
\hline \multirow{6}{*}{ Advantage } & $\begin{array}{c}\text { Good corrosion } \\
\text { resistance }\end{array}$ & $\begin{array}{l}\text { Atmospheric } \\
\text { corrosion } \\
\text { resistance }\end{array}$ & $\begin{array}{l}\text { Cheaper than } \\
\text { stainless steel }\end{array}$ \\
\hline & $\begin{array}{c}\text { Good } \\
\text { mechanical } \\
\text { properties }\end{array}$ & $\begin{array}{c}\text { Tensile strength } \\
\text { properties }\end{array}$ & $\begin{array}{c}\text { Than stainless } \\
\text { steel surface } \\
\text { treatment }\end{array}$ \\
\hline & $\begin{array}{c}\text { Good } \\
\text { mechanical } \\
\text { properties }\end{array}$ & $\begin{array}{c}\text { Strong } \\
\text { adaptability }\end{array}$ & $\begin{array}{c}\text { No high } \\
\text { Intensity } \\
\text { stainless steel }\end{array}$ \\
\hline & $\begin{array}{l}\text { Good thermal } \\
\text { performance }\end{array}$ & Intensity Hard & $\begin{array}{l}\text { Good } \\
\text { oxidation } \\
\text { resistance }\end{array}$ \\
\hline & $\begin{array}{l}\text { Can design } \\
\text { good }\end{array}$ & $\begin{array}{c}\text { Strong } \\
\text { antioxidant }\end{array}$ & Good tensile \\
\hline & Excellent craft & Long life & \\
\hline \multirow{4}{*}{ Disadvantage } & $\begin{array}{c}\text { Low elastic } \\
\text { modulus }\end{array}$ & $\begin{array}{c}\text { High prices, big } \\
\text { weight }\end{array}$ & $\begin{array}{l}\text { susceptible to } \\
\text { lightning strike }\end{array}$ \\
\hline & $\begin{array}{c}\text { Poor moisture } \\
\text { resistance }\end{array}$ & Poor plasticity & $\begin{array}{l}\text { High density } \\
\text { heavy quality }\end{array}$ \\
\hline & Easy to aging & $\begin{array}{c}\text { Rust easily, } \\
\text { poor aesthetics }\end{array}$ & $\begin{array}{c}\text { Poor corrosion } \\
\text { resistance }\end{array}$ \\
\hline & $\begin{array}{l}\text { Low interlayer } \\
\text { shear strength }\end{array}$ & $\begin{array}{l}\text { Processing } \\
\text { complex }\end{array}$ & \\
\hline
\end{tabular}

\section{SOLAR PHOTOVOLTAIC MODULE ALUMINUM FRAME}

\section{A. The Role Of Aluminum Frame}

Because solar panels need to run in many harsh conditi ons, to withstand wind and rain, to withstand external force, but also to ensure that the solar modules within the frame $f$ rom damage, thus ensuring the normal output power perfor mance, and the need to adapt a variety of purposes, so the $r$ ole of the border is very important.

Aluminum frame has a role:

(1) to protect the glass edge;

(2) Aluminum alloy combine to strengthen the playing side silica gel sealing performance components;

(3) greatly improves the mechanical strength of the overall components;

(4) easy to install components, transportation ${ }^{[9]}$.

\section{B. Aluminum Frame Structure}

Aluminum frame structure is divided into two categori es: one is the tape of aluminum frame structure, is a silica gel aluminum frame structure;

Table II aluminum frame structure features comparative table

\begin{tabular}{ccc}
\hline & $\begin{array}{c}\text { tape aluminum frame } \\
\text { structure }\end{array}$ & $\begin{array}{c}\text { silica gel aluminum } \\
\text { frame structure }\end{array}$ \\
\hline Advantage & Relatively simple & high adhesive strength \\
structure & Complex structure than \\
Disadvantage & Sealing performance & the former \\
& somewhat less & the
\end{tabular}

\section{Aluminum frame fixed manner}

Aluminum frame is fixed in two ways: angle aluminu $\mathrm{m}$ riveting, taptite screws countersunk head connection.

Table III aluminum frame fixed manner Features comparative table

\begin{tabular}{ccc}
\hline Angle aluminum riveted & $\begin{array}{c}\text { Self-tapping screw } \\
\text { connections }\end{array}$ \\
\hline Advantage & $\begin{array}{c}\text { High installation } \\
\text { efficiency, } \\
\text { connecting solid } \\
\text { structure }\end{array}$ & $\begin{array}{c}\text { Itself has a strong } \\
\text { corrosion resistance }\end{array}$ \\
Disadvantage & hecause there are nail & \\
& holes, & Connection strength is \\
& Intensity weakened & not high \\
\hline
\end{tabular}

\section{Surface treatment of aluminum frame}

Because Solar Photovoltaic Module to ensure that the outdoor life of 25 years or so, so the aluminum frame Solar Photovoltaic Module used to have good resistance to oxidation and corrosion-resistant properties. Borders are generally used in Solar Photovoltaic Module into anodizing, sandblasting oxidation and oxidative electrophoresis three ${ }^{[10]}$. 
Table IV Comparison between the surface treatment of aluminum frame

\begin{tabular}{|c|c|c|c|}
\hline \multirow{7}{*}{} & $\begin{array}{c}\text { Anodic } \\
\text { oxidation }\end{array}$ & $\begin{array}{c}\text { Sandblasting } \\
\text { oxidation }\end{array}$ & $\begin{array}{c}\text { Electrophoresis } \\
\text { Oxidation }\end{array}$ \\
\hline \multirow{4}{*}{ Advantage } & $\begin{array}{c}\text { Anti-erosion } \\
\text { ability } \\
\text { High surface } \\
\text { hardness }\end{array}$ & Enhanced corrosion \\
& $\begin{array}{c}\text { Good } \\
\text { insulation } \\
\text { Good heat }\end{array}$ & High hardness & resistance \\
& resistance & & Increase the \\
& Decorative & & Prevent abrasion \\
& fine & & Good heat \\
& expensive & inexpensive & inexpensive \\
\hline Cost & & & Good aesthetics \\
\hline
\end{tabular}

\section{SOLAR PV BORDER SITUATION ANALYSIS AND PROBLEMS}

\section{A. Solar PV border situation analysis}

\section{1) Solar PV module frame Features of the status quo}

Since solar components product specifications, production processes, there is a difference components practical application environment, and in order to reflect its intuitive product features, each solar module manufacturers border with customizable features and diversity $^{[11]}$.

\section{2) Quality Solar Photovoltaic Module frame analysis of the status quo}

Solar products are refined border deep processing prod ucts, strict quality requirements, including:

(1) Product appearance detection. If the existence of the s olar frame scratches, abrasions, bumps and other issues, w ill lead to the border surface exposed after long-term outd oor operation of solar modules susceptible to corrosion, w ill affect the entire service life of components. Meanwhile, the Product appearance for the solar components grade ra ting an important factor, if the product does not meet the $r$ equirements of the appearance, the solar modules in the fi nal sales will be downgraded ${ }^{[12]}$.

(2) Product hardness, weather ability detection. Because solar modules for outdoor installation, the use of a long, $n$ eed to consider the carrying capacity of the product under the influence of the external environment of wind, snow 1 oad, etc., if insufficient solar frame stiffness, deformation and thus will lead to failure of the entire assembly ${ }^{[13]}$. Mea nwhile, the need to consider the impact of natural acid, alk ali, UV, heat, alternating hot and cold conditions, so the $\mathrm{fr}$ ame surface treatment, the material composition of the bor der, there are strict requirements, if functional failure will cause the seal and the protective effect of components fail ure, thereby reducing components overall performance ${ }^{[14]}$. (3) Product detection accuracy. Solar border Accuracy incl udes: a, section dimension of accuracy, including glass tan $\mathrm{k}$ or cross-sectional lumen package size accuracy, precisio $\mathrm{n}$ screw holes, surface bending and twisting degree; b, pre cision machining dimensions: length, including machining, cutting angle, cutting off the poor, functional structure of precision, high accuracy requirements of solar border prod ucts $^{[15]}$

\subsection{Solar Photovoltaic Module frame Problems \\ (1) Solar frame weight, high cost}

The current solar frame weight is too big, not easy to $\mathrm{i}$ nstall and transport, and because the solar cells are made $o$ $\mathrm{f}$ aluminum alloy frame multi-material, resulting in high $\mathrm{p}$ roduction cost of solar cells border ${ }^{[16]}$.

(2) Solar module frame structure sealing performance is poor

During assembly, particularly components area is larg er, since the glass itself arch-shaped or curved waveform c haracteristics, coupled with the product's own center of gr avity is the downward direction, the product will be the ce ntral drooping, upturned ends, in the present will extrusio n equipment commonly used manual or pneumatic border from the four corners of the tank where a lot of sealants, al though many began to enter the amount silica gel, and als o the presence of silica gel products up and down the sides of the uneven, some places do not even have the sealant $\mathrm{s}$ ealing uniformity is difficult to control, sealing performan ce is difficult to guarantee, components prone to delamina ting product edges, electrical insulation decline and other i ssues, the need to improve further ${ }^{[17]}$.

(3) Solar Borders low life

Existing solar frame made of aluminum alloy, the ther mal expansion coefficient of aluminum is five times that 0 f glass, so that the front plate solar panel frame with solar panels under cold conditions change, due to the expansion coefficient of the gap is too large since the loss arising fro $\mathrm{m}$ the impact of solar energy board life $\mathrm{e}^{[18]}$.

(4) Solar border perishable

Existing solar located below the border in contact with steel solar stent, made of aluminum solar frame susceptib le to galvanic corrosion ${ }^{[19]}$.

(5) Solar structural stability of the border is relatively low

Due to the current widespread use of solar energy pack ages will often produce long border corner border junction with short height dislocation, dislocation and around the $c$ orner joints and other defects. A lower frame structure of $t$ he conventional four border stability encapsulated solar ce ll module, its tensile strength is relatively low. Convention al border component's border thicker, it is more a single fi xed method, and in the solar modules by external force, to produce solar modules easily cracked or broken ${ }^{[20]}$.

\section{DEVELOPMENTS AND DOMESTIC AND}

INTERNATIONAL TRENDS OF SOLAR PV MODULES BORDER

\section{A. The development of solar photovoltaic modules of the} border

Due to Europe, Japan and other developed solar modul e manufacturers earlier time, in the early development of $\mathrm{s}$ olar energy in the region borders the basic procurement, le $\mathrm{d}$ a group of high quality, rich experience in the design of solar border suppliers, including Sweden, Sapa, Japan San kyo Tateyama Aluminum Corporation, Germany TS-Solar, Hydro Aluminum America and so on ${ }^{[21]}$. These companie $\mathrm{s}$ are mainly large aluminum plant, its main competitive a dvantages for product quality advantages, but its price is $r$ elatively high, about 30\% $-40 \%$ higher than the domestic s 
olar border products. With domestic solar border continuo usly improve product quality, the foreign component man ufacturers to reduce costs, will gradually shift its procure ment China ${ }^{[22]}$.

China's solar energy industry has gone through the border following three stages:

Prior to 2005 borders domestic solar industry has not y et formed, domestic solar module manufacturers relatively dispersed. This stage, the solar industry as a whole smalle r frame, most border plant mainly solar module manufactu ring companies to support the development of the enterpri se, customer structure is relatively simple, the main suppl y peripheral components manufacturer ${ }^{[23]}$.

Since 2009, the domestic solar industry is growing rap idly border. The actual amount of new installed capacity $\mathrm{i}$ n 2010 than 500MW. Domestic PV installed in 2011 the $\mathrm{t}$ otal reached 2.9GW, compared with 2010, an increase of 500 per cent of the total. 2013 domestic photovoltaic new capacity $11.3 \mathrm{GW}$, accounting for $30.5 \%$ of global installe d capacity, the 2014 domestic capacity has reached 14GW. By the end of 2014, China's total installed capacity of 30 GW, after Germany, the rapid growth of demand also cont ributed to the rapid development of China's solar energy i ndustry borders. Because of China's solar industry has a st rong frame price advantage, and the product quality and te chnical level has been significantly improved, the foreign component manufacturers gradually expand procurement $f$ rom China solar frame ratio is currently China is already $\mathrm{t}$ he world's largest supplier of solar border ${ }^{[24]}$.

\section{B. The development trend of solar border}

With the advancement of science and technology, the development of solar border more quickly, now with or wi thout borders solar modules. Borders trends include fine, l ightweight, high strength and integration.

(1) Fine: automated production trend component of the bor der to further improve product accuracy requirements.

(2) Lightweight: The product does not affect the function o $\mathrm{f}$ the premise, from product design to reduce the weight of the material in the process, while reducing production cos ts, while reducing transportation costs.

(3) High intensity: higher-strength products relatively smal ler, easy to transport, and better performance.

(4) Integration: mainly refers to the design of integrated bo rder to facilitate post installation, including borders and ar chitecture, engineering combined with integrated design, s uch as BIPV (building integrated photovoltaic); and the b order with the mounting bracket integrated design.

\section{SUMMARY AND PROSPECT}

With the extensive use of aluminum alloy frame, composite frame slowly emerge, industrial escalating border. In focusing on the development of the border at the same time, the problems in the border should be resolved accordingly, such as border susceptible to corrosion, heavy, structure and poor sealing performance. Bracket border integration and building integrated photovoltaic and other advanced technology is the development trend of the future, the industry will continue to develop the border makes the PV industry progress.

\section{ACKNOWLEDGMENT}

This work was financially supported by A project Fun ded by the Priority Academic Program Development of Ji angsu Higher Education Institutions (PAPD); Jiangsu poli cy guidance class program (Cooperative) Project: Researc h of PV Mounting System for Solar Power Station and it' s key technology (June 2015 has been publicized) and th e Nantong University Natural Science Foundation (No.14 H118).

\section{REFERENCES}

[1] Li Lei, Yang Chun; Strategy status quo of China's photovoltaic industry and sustainable development [J]. Foreign Energy, 2012, 17 (4): 28-37.

[2] Li Xiaoguang. International growth strategy of China's solar PV ind ustry [D]. Beijing: Beijing University of Technology, 2012.

[3] Chen Fengnan, Wang Limao; Analyze the spatial pattern of China's solar photovoltaic industry and its influencing factors [J]. Resources Science, 2012, 34 (2); 287-296.

[4] Wang Wenxiang, Shi Yanxin. The formation of China's PV industry dilemma: path, mechanism and policy reflection [J]. Contemporary Finance \& Economics, 2014, 4(1): 87-98.

[5] Wang Yonghua, Luo Guoliang, Guo Yiwei. Why is there overcapac ity in China's PV industry in its early growth stage[J]. Renewable E nergy, 14, 72(10): 188-194.

[6] Dale, Michael, Benson, Sally; Energy balance of the global photovo ltaic (PV) industry--is the PV industry a net electricity producer[J]. Environmental science \& technology, 2013, 47(7): 3482-3489.

[7] Mitsuyuki, Maeda. Key to Success for Japanese PV Industry[J]. De velopment engineering, 2011, 30(1): 67-71.

[8] Chen, L, Zhao, Ch, L, Zhou, Zh, G, Liu, W, J, Wang.PV demand an d supply in China[J]. Prog. Photovolt: Res. Appl, 2013, 21(6): 45-5 1.

[9] Ren Junhai, Li Meili. Research on the impact of solar module alumi num frame component costs [J]. Industry and Technology Forum, 2 012, 11 (14): 60-61

[10] AKCOME technology. AKCOME technology to become integrate d parts suppliers PV industry [J]. Securities Market Weekly, 2011, (30): 79-80.

[11] Liu Liangyong. Borders Group corner panels reliability analysis [C]. Jinan: Third International Photovoltaic Power Generation Conf eren ce, 2009. 119-121.

[12] Li Fenlv. Photovoltaic solar aluminum profiles production process control [C]. China: 2010 Aluminum Technology (International) For um Collection, 2010. 323-330.

[13] Wang Dong, Cao Shenglong. PV modules with the optimized fram e design [C]. Shanghai: Twelfth China PV Conference, 2012.

[14] Hu Zhenghui. Aluminum solar frame closed the main problems in t he temperature and control measures [C] Guangdong: Third Guang dong Aluminum Technology Seminar, 2012. 78-81.[15] LI Yinbo, Liu Yuejin. FEM solar laminates and aluminum frame connected an alysis [C] JinaThird International Photovoltaic Power Generation C onference, 2009. 48-50.

[16] Liu Peng, Yu Qingsong, Wang Weihua. Development and applicati on of solar PV modules with a two-component silicone sealant [C] Shanghai: Shanghai Municipal Association of bonding technology f irst academic year will be the seventh, 2012. 47-56.

[17] Liu Feng, Zhang Jun, Li Chenghui, You Xiaozeng. PV module enca psulation material progress [J]. Journal of Inorganic Chemistry, 201 2, 28 (3): 429-436.

[18] Xu Lili. Aluminum solar protection [C]. Shanghai: 2010 Annual M eeting of anti-corrosion coatings, 2010. 87-88.

[19] Guo Feng. Terrestrial photovoltaic development [J]. Electronic equi pment, 2008, 8 (165): 56-60.

[20] Han Xue, Lu Jia. No Border solar module solutions [Z] Chinese:. 3 M China Ltd., 2013.

[21] Huang Xiang, Gang Gewen, Yu Chao. Factors solar photovoltaic p ower plant design analysis [J]. Huadian Technology, 2013, 35 (2): 7 9-86.

[22] Li Xiangzhi, Sun Yunlin, Shen Hui. Northwest Research saline soil affect the installed base of large ground photovoltaic power station [C] Beijing: The 12th China PV Conference, 2012. 
[23] Wu Dacheng. China's photovoltaic module encapsulation equipmen t manufacturing Situation and Prospect [J]. Solar, 2012, (08): 14-16.

[24] Liu Haibo. The development trend of photovoltaic module encapsul ation equipment industry analysis [C] Hebei: Baoding Yingli New Energy Resources Co., Ltd., 2012. 365-366. 